\title{
Phenotypic Characterization of Auxotrophic Mutant of Nontyphoidal Salmonella and Determination of Its Cytotoxicity, Tumor Inhibiting Cytokine Gene Expression in Cell Line Models
}

\section{Kadeeja Jazeela}

Nitte University Centre for Science Education and Research

\section{Anirban Chakraborty}

Nitte University Centre for Science Education and Research

\section{Akshatha Kotian}

Nitte University Centre for Science Education and Research

\section{Vankadari Aditya}

Nitte University Centre for Science Education and Research

Krishna Kumar Ballamoole

Nitte University Centre for Science Education and Researcg

\section{Praveen Rai}

Nitte University Centre for Science Education and Research

\section{Indrani Karunasagar}

Nitte University Centre for Science Education and Research

VK Deekshit ( $\nabla$ deekshit1486@nitte.edu.in )

Nitte University Centre for Science Education and Research https://orcid.org/0000-0002-3535-5528

\section{Original Paper}

Keywords: non-typhoidal Salmonella, auxotrophic mutant, cytokines, virulence genes, tumor therapy

Posted Date: February 4th, 2021

DOI: https://doi.org/10.21203/rs.3.rs-170220/v1

License: (c) (i) This work is licensed under a Creative Commons Attribution 4.0 International License. Read Full License

Version of Record: A version of this preprint was published at Archives of Microbiology on March 26 th, 2021. See the published version at https://doi.org/10.1007/s00203-021-02243-4. 


\section{Abstract}

An auxotrophic mutant of non-typhoidal Salmonella (NTS) strain was phenotypically characterized in this study. The characterization was based on phenotype, morphology, motility, biofilm forming ability, growth kinetics, etc. The phenotypic results from the above experiments determined that the mutant showed variation in phenotypic characters from that of wild-type strain. Subsequently, mutant and wild-type NTS were subjected to epithelial cell invasion and intracellular replication assays. The real time PCR analysis was also performed to analyse expression of tumor inhibiting cytokine genes and virulence genes post bacterial infection in cell lines. The mutant showed highest invasion potential than wild-type NTS whereas the replication of mutant was slower in both the cell lines. Similar to the wild-type strain, the mutant also retained the cytotoxic potential when analysed in vitro. Furthermore, the expression of proinflammatory cytokine genes such as TNF- $a$ and $I L-1 \beta$ was upsurged with the downregulation of anti-inflammatory cytokine genes like TGF- $\beta$, IL- 6 and $I L-10$ post infection of the mutant strain in cell lines. In addition, virulence genes of Salmonella pathogenicity island one and two of mutant were downregulated in vitro except invA in HeLa cell line. Therefore, the auxotrophic mutant showed positive attributes of a potential antitumor agent in terms of expressing tumor inhibiting cytokine genes when assessed in vitro. Though the study did not check the tumor inhibitory effect of NTS strain directly, findings of the study emphasizes on the development of a novel strain of NTS with less virulence and more immunogenic traits to inhibit tumor cells.

\section{Introduction}

Cancer is a multifactorial disease causing high morbidity and mortality worldwide every year. The diverse factors that are associated with the development of certain cancers include genetic background, age, diet, smoking, exposure to pollutants, alcohol consumption, body weight, microbial infection etc., leading to global cancer mortality (Ashu et al. 2019). Due to the lack of effectiveness and inadequate tumor penetration in conventional therapies like chemotherapy, radiation therapy etc., cancer therapy has not gained much success (Khawar et al. 2015). This has turned the attention to look for better alternative therapeutic strategies. Therefore, the immunotherapeutic approach of tumor treatment was explored which thereby proved novel wherein it escalated the effectiveness of identifying and selectively mounting on the tumor cells to produce antitumor response by sparing the surrounding healthy tissues (Nagarsheth et al. 2017). The immunotherapies such as checkpoint inhibitors, monoclonal antibodies, anti-cytotoxic T-Lymphocyte associated protein 4 (CTL-4) and programmed death protein 1 (PD1) targeted immunotherapy are being tried in clinical trial (Torres et al. 2018; Scheiner et al. 2019) but was not successful as anti-oncolysates because it reduced the immune tolerance capacity due to its systemic administration. This has prompted the use of an alternative therapy such as bacteria mediated cancer therapy to cause cancer cell destruction. The practice of bacterial application targeting tumor cells dates back to the age of William B. Coley, an American oncologist who observed the role of bacteria in demolishing tumor in patients with acute bacterial infections in the late $19^{\text {th }}$ century (Kramer et al. 2018). Coley's work didn't gain adequate attention due to the incomplete understanding of the mechanism behind its tumor regression. Hence, the focus was shifted to radiation therapy and chemotherapy to destroy tumors. Nevertheless, these strategies didn't succeed in eliminating tumor completely and it resulted in severe side effects (Jazeela et al. 2020). Thereafter, the bacterial mediated tumor therapy renewed and many different bacterial species with immunogenic and anticancer potential are currently being explored. So far, the oncolytic nature of various bacterial strains such as Mycobacterium bovis, Listeria monocytogenes, Clostridium, 
Salmonella Typhimurium etc., have been explored in vivo (Adkins et al. 2012) due to their distinctly colonizing and rapid proliferating nature in the tumor microenvironment. Amongst these, $S$. Typhimurium was extensively studied in vitro where in it showed effective invasion and destruction of broad range of cancer cell types and in vivo in oxygenic and anoxygenic tumor regions (Hoffman 2016). Thus, this bacterium was regarded as the master strain in the experimental cancer therapy analysed till date. The $S$. Typhimurium VNP20009 $\Delta m s b B /$ $\Delta p u r l$ (lipid A and purine auxotrophic mutant) is one among various mutants of $S$. Typhimurium which was taken to phase 1 clinical trial after it was tested for its efficacy in mice and swine; but it resulted in treatment failure due to over attenuation (Toso et al. 2002) and also because of its toxicity in bone marrow, spleen and liver when injected intra-tumorally (Mercado-Lubo and McCormick 2017). According to Zhang et al. other mutants of the $S$. Typhimurium like A1-R auxotrophic mutant, proved to be more potent antitumor agent when compared to VNP20009 strain and showed inhibition of Lewis lung carcinoma (Zhang et al. 2015). In mouse models, monotherapy of A1-R auxotrophic mutant was effective against primary and metastatic human prostate, breast, and pancreatic cancer in addition to osteosarcoma, fibrosarcoma, and glioma (Hoffman 2016). A1-R also showed positive attributes towards destruction of tumors with high vascularity (Liu et al., 2010) and it encouraged stem like and non-stem cancer-cell death in vivo, indicating that chemo-resistant cancer stem-like cells could be lysed by A1-R mutant (Hiroshima et al. 2013). Another mutant of $S$. Typhimurium defective in the ppGpp synthesis ( $\triangle \mathrm{ppGpp}$ : depletion of relA and $s p o T$ ) exhibited the up regulation of certain tumor supressing cytokine genes like $I L-1 \beta, I L-18$ and TNF- $a$ and also triggered the production of NLRP3, IPAF (inflammasome coding genes) in MC38 and CT26 in colon cancer murine models (Zheng et al. 2017). S. Typhimurium aroA-aroD double mutant (harbouring the Flt3 Ligand) is a genetically-engineered strain which was targeted against melanoma in mice model and it showed $50 \%$ tumor suppression but soon resulted in low fitness within the tumor and this strain was regarded as the Class I mutants (Arrach et al. 2010) which was less potent than Class 2 mutants in suppressing tumor growth. The anticancer property shown by $S$. Typhimurium is also elicited by the passive instigation of the infiltrating pro-inflammatory cytokines upon its injection via intravenous route (Crull et al. 2011). Tumor lysis was observed when the pro-inflammatory cytokines like IL-1ß and TNF-a were released post Salmonella infection where in apoptosis-induced tumour cell death was shown by TNF-a and both helper and cytotoxic T-cell induced tumour cell death was exhibited by IL-1ß (Kim et al. 2015).

Over the past several years, different mechanisms of bacteria-tumor interactions in addition to conventional antitumor therapies were studied in vitro and in vivo to successfully eradicate cancer cells but the results were unreliable. Therefore, it is always desirable to use less virulent serovar of Salmonella in order to reduce the toxic effects to healthy cells. Hence, in this study an auxotrophic mutant of a non-typhoidal Salmonella (NTS) serovar, Salmonella Oslo generated in our previous study was characterised and explored for its role in triggering the tumor suppressing cytokine genes in cell line models.

\section{Materials And Methods}

\section{Bacterial strains}

An auxotrophic mutant of Salmonella Oslo generated in our previous study (Jazeela et al. 2020) was further characterised phenotypically in this study. The wild-type strain of NTS was used as the control strain for all the experiments undertaken in this study. 


\section{Phenotypic characteristics}

Phenotypic confirmation of the suspected transformants along with the wild-type bacteria as a positive control were done by streaking the cultures on minimal agar medium (HiMedia, Laboratories Pvt. Ltd., India) supplemented with and without amino acids leucine and arginine. A non-selective agar media, Luria-Bertani agar (LBA) was also used as an enriched media to check for the growth of the transformants as master plate. The strains were also streaked on selective and differential agar plates of Salmonella such as Xylose Lysine Deoxycholate (XLD) (HiMedia, Laboratories Pvt. Ltd., India) and Hektoen Enteric Agar (HEA) (HiMedia, Laboratories Pvt. Ltd., India) to differentiate the growth pattern (data not shown). After incubating them at $37^{\circ} \mathrm{C}$ for sufficient period of time, the plates were observed for the growth of the mutants and compared it with the wild-type strain.

\section{Morphological characteristics}

The auxotrophic mutant strain obtained was checked for its morphological difference in LBA and was compared with the wild-type strain. Briefly, bacterial strains were revived in a $5 \mathrm{ml} \mathrm{LB}$ broth medium and incubated at $37^{\circ} \mathrm{C}$ until a mid-log phase culture is obtained. One $\mathrm{ml}$ of these cultures were centrifuged at $8000 \mathrm{x}$ $\mathrm{g}$ for $5 \mathrm{~min}$. The supernatant was discarded, and cell pellets were resuspended in $1 \mathrm{ml}$ of the PBS (HiMedia, Laboratories Pvt. Ltd., India) and it was serially diluted in different concentrations like 1:10, 1:100 etc. From each dilution, $100 \mu \mathrm{L}$ of the diluted samples were plated on LBA and incubated at $37^{\circ} \mathrm{C}$ for overnight growth. Plates were observed for the appearance of colonies after 24-48 $\mathrm{h}$ and the results were recorded.

\section{Motility assay by soft agar stabbing}

The motility of mutant and wild-type strain was checked by growing them in soft agar medium. Briefly, both the cultures were inoculated to soft agar containing $1 \%$ tryptone, $0.5 \% \mathrm{NaCl}$ and $0.5 \%$ agar ( $\mathrm{wt} / \mathrm{vol}$ ). The cells were incubated at $37^{\circ} \mathrm{C}$ to an optical density of $0.6 \mathrm{OD}_{600}$. Inoculation of these cultures was done by using sterile straight needle by stabbing through the centre of the semisolid agar tubes approximately one-half the depth of the medium. These tubes were incubated at $37^{\circ} \mathrm{C}$ for $4 \mathrm{~h}$ and observed for the growth of the culture. The incubation was continued for an additional day or more (24-48 h). The motility was observed based on the diffused growth produced by the strains.

\section{Bacterial growth kinetics}

The growth kinetics of both the wild-type and mutant strain was compared. Briefly, an overnight grown culture with $0.6 \mathrm{OD}_{600}$ was inoculated to a flask containing $200 \mathrm{ml}$ LB broth to obtain an initial OD of 0.001 at zero hour. The flask was then incubated at $37^{\circ} \mathrm{C}$ in a shaker incubator (New Brunswick, Eppendorf) at $200 \mathrm{rpm}$ for varying period. The optical density was measured at $600 \mathrm{~nm}$ from 0-30 h using a spectrophotometer (Eppendorf BioPhotometer ${ }^{\circledR}$ D30, Germany). The experiments were performed in triplicates. The statistical differences between the growth of these strains were calculated by two-way ANOVA. A $p$-value less than 0.05 were considered as statistically significant.

\section{Biofilm assay}


Biofilm assay was performed and quantified in polystyrene microtiter plates (Eppendorf, Germany) (Stepanović et al. 2004). Briefly, $230 \mu \mathrm{L}$ of trypticase soy broth (TSB) (HiMedia Laboratories Pvt. Ltd., India) was added to 96 well flat bottom polystyrene microtiter plates. About $20 \mu \mathrm{L}$ of the overnight cultures of both wild-type and mutant strains were added to each well. The microtiter plates were incubated for $24 \mathrm{~h}$ at $37^{\circ} \mathrm{C}$. Following incubation period, the plate contents were discarded and washed thrice with sterile $1 \mathrm{x}$ phosphate buffered saline (PBS) (HiMedia, Laboratories Pvt. Ltd., India). About $150 \mu \mathrm{L}$ of methanol was added to fix the cells and $200 \mu \mathrm{L}$ of $1 \%$ crystal violet to stain it. Post staining, $200 \mu \mathrm{L}$ of glacial acetic acid (thirty three percent (v/v) was used to resolubilize. Then the plate was measured for its absorbance value at $630 \mathrm{~nm}\left(\mathrm{OD}_{630}\right)$ in an ELISA reader (ELX 800, Bio-Teck Instrument, USA) and based on this result, bacterial strains used were classified as strong, moderate, weak and non-biofilm former. The experiments were performed in triplicates. True biofilm level was obtained after subtracting the optical density values of sterile control from the test values. The cut-off optical density was defined as 3 standard deviations above the mean O.D of the negative control (Bhowmick et al. 2011).

\section{In vitro assays using wild-type and mutant strains}

\section{Determination of epithelial cell invasion and intracellular replication in HEK-293 and HeLa cell lines using wild- type and mutant Salmonella Oslo strains}

The HEK-293, RRID: CVCL_0045 and HeLa, RRID: CVCL_0030 cell lines were procured from National Centre for Cell Science (NCCS), Pune, India and preserved at $-196{ }^{\circ} \mathrm{C}$ after passaging. These cell lines were then revived and plated into 24 well cell culture plates (Eppendorf, Germany) at $1.5 \times 10^{5}$ (HeLa/HEK-293 cells/well) and incubated for $24 \mathrm{~h}$ at $37{ }^{\circ} \mathrm{C}$ with $5 \% \mathrm{CO}_{2}$. Monolayer of cells with $70-80 \%$ confluence was selected for further experiment. The plates were washed with Dulbecco's phosphate buffered saline (D-PBS) (HiMedia, Laboratories Pvt. Ltd., India) prior to bacterial infection to remove the antibiotic content present in the pre-existing medium and then further supplied with the DMEM medium containing 10\% Fetal Bovine Serum (FBS) w/o antibiotics. These plates were incubated at $37^{\circ} \mathrm{C}$ until the $\mathrm{OD}_{600}$ of the bacterial culture reached 0.6 . Bacteria at the multiplicity of infection (m.o.i) of 10 were infected on to cell lines and epithelial cell invasion and intracellular replication were carried out (Blanc-Potard et al. 1997; Rakeman et al. 1999; Freeman et al. 2003) with minor modifications. Bacterial cells were counted by plating $100 \mu \mathrm{l}$ of different dilutions on non-selective agar plates at $2 \mathrm{~h}$ and $16 \mathrm{~h}$ post infection. Epithelial cell invasion was assessed by the number of bacteria recovered at $2 \mathrm{~h}$ and intracellular replication was measured by the ratio of bacteria recovered at $16 \mathrm{~h}$ to the number of bacteria at $2 \mathrm{~h}$. All the experiments were performed in triplicates. The data obtained as result of epithelial cell invasion and intracellular replication of bacterial strains in cell lines were subjected to unpaired Student's $t$-test with $5 \%$ significance level.

\section{Determination of cytotoxicity assay in HEK-293 and HeLa cell lines using wild-type and mutant Salmonella strains}

Evaluation of cytotoxicity caused by wild-type and mutant Salmonella strains in HeLa and HEK-293 cell lines was carried out from 0-24 hpi and compared the difference between the cytotoxic potential of these strains. Cell free supernatant of every time points were subjected to Lactate Dehydrogenase assay (LDH). LDH activity was determined as per manufacturer's protocol (Roche Applied Science; Indianapolis, IN) (Bhunia et al. 1994;Maldonado et al. 2005) which quantifies the amount of LDH release from the cell lines to the supernatant 
upon cell lysis. Cell free supernatant from uninfected cell lines remained as the negative control. The reaction was read in an ELISA reader (ELX 800, Bio-Teck Instrument, USA) to measure the absorbance of the sample at $490 \mathrm{~nm}$ using Gen5 software. The experiments were carried out in triplicates.

\section{Infection of SO1 and LAT9 on epithelial cell lines and extraction of total RNA}

Epithelial cell infection with the bacterial strains was carried out in T75 cell culture flasks (Eppendorf, Germany) according to the standard protocol (as mentioned earlier). Following bacterial infection, the T75 cell culture flasks were incubated for different time intervals viz $0 \mathrm{~h}, 2 \mathrm{~h}, 4 \mathrm{~h}, 6 \mathrm{~h}$ at $37^{\circ} \mathrm{C}$ in an incubator supplied with $5 \%$ $\mathrm{CO}_{2}$. The growth medium was discarded following incubation period, and the epithelial cells were detached using $0.25 \%$ Trypsin-EDTA (HiMedia, Laboratories Pvt. Ltd., India) and the cells were collected in DMEM containing 10\% FBS in $15 \mathrm{ml}$ centrifuge tubes (Eppendorf, Germany). This cell suspension was centrifuged at 4 ${ }^{\circ} \mathrm{C}$ for $15-20 \mathrm{~min}$ at $4000 \mathrm{rpm}$ to collect the cell pellet and it was subjected for RNA extraction using the RNeasy mini Kit (Qiagen, Germany) according to the manufacturer's instructions with minor modifications.

\section{cDNA synthesis}

The RNA samples were further subjected for DNase treatment (Thermo Fisher Scientific, USA) according to the manufacturer's guidelines to remove the remnant DNA. The quality and quantity of the RNA was measured using Nanophotometer (IMPLEN, Germany). The RNA samples obtained were normalised to one microgram for cDNA synthesis. The reverse transcription of the RNA samples was carried out using Reverse Transcription kit (Takara Bio USA, Inc.) according to the manufacturer's instructions. Gene expression was measured by using SsoFast EvaGreen Supermix (BioRad, USA) with minor modifications. Briefly, one microgram of each RNA samples with $50 \mu \mathrm{M}$ of random hexamers were denatured at $65^{\circ} \mathrm{C}$ for $5 \mathrm{~min}$ and added to the reaction mixture containing 5 X PrimeScript Buffer ( $50 \mathrm{mM}$ Tris- $\mathrm{HCl}$ with $\mathrm{pH} 8.3,375 \mathrm{mM} \mathrm{KCl}$ and $15 \mathrm{mM} \mathrm{MgCl}_{2}$ ), 20 units of RNase inhibitor, $10 \mathrm{mM}$ of dNTP mix and 100 units of PrimeScript reverse transcriptase. The reaction mixture was incubated at $42{ }^{\circ} \mathrm{C}$ for $60 \mathrm{~min}$ followed by heating at $72{ }^{\circ} \mathrm{C}$ for $10 \mathrm{~min}$ and then cooled to $4{ }^{\circ} \mathrm{C}$. CDNA samples were stored at $-20^{\circ} \mathrm{C}$ until further use.

\section{Expression of cytokine genes and virulence genes post bacterial infection in different cell lines by quantitative real time polymerase chain reaction (RT- qPCR)}

The expression level of the cytokine genes (Table 1) expressed by the cell lines as a result of bacterial infection as well as the expression of bacterial virulence genes (Table 2) were quantified by qPCR at different time on HEK-293 and HeLa cell lines. Appropriate housekeeping genes such as RP-II (RNA polymerase II) for cytokine gene expression and $i c d A$ (Isocitrate dehydrogenase) for virulence gene expression were selected. The real-time PCR primers were designed using Primer3 software and optimum concentrations of primers were determined following standardization. The qPCR analysis was carried out using SsoAdvanced ${ }^{\text {TM }}$ universal SYBR green Supermix (BioRad, USA) with minor modifications. The total reaction mixture $(10 \mu \mathrm{l})$ consisted of $5 \mu \mathrm{l}$ of advance $2 X$ universal SYBR green super mix, $200 \mathrm{nM}$ of forward and reverse primers for cytokine genes/100 nM of forward and reverse primers for virulence genes, and $1 \mu \mathrm{l}$ of cDNA samples each and adjusted to $10 \mu \mathrm{l}$ by adding nuclease free water (HiMedia Laboratories Pvt. Ltd., India). The reaction was performed in a real-time detection system (CFX96 Touch $^{\text {TM }}$, BioRad, USA) with cycling conditions as follows: initial denaturation at $95^{\circ} \mathrm{C}$ for $3 \mathrm{~min}$ followed by 39 cycles of denaturation at $95^{\circ} \mathrm{C}$ for $10 \mathrm{~s}$, primer annealing temperature at $55^{\circ} \mathrm{C}$ for $30 \mathrm{~s}$ 
for cytokine genes and 45 cycles of denaturation at $95^{\circ} \mathrm{C}$ for $10 \mathrm{~s}$ for virulence genes which had an annealing temperature of $54{ }^{\circ} \mathrm{C}$ for $20 \mathrm{~s}$ and elongation at $72{ }^{\circ} \mathrm{C}$ for $20 \mathrm{~s}$. The amplification data was acquired by BioRad CFX Manager at the end of each elongation step. The expression of target genes was normalized to $R P$-II (housekeeping gene) during analysis of cytokine genes and icdA (housekeeping gene) when virulence gene expressions were analyzed respectively. The analysis of relative gene expression was carried as described previously (Livak and Schmittgen 2001). The data obtained from the real-time PCR were statistically analyzed by independent sample $t$-test with $5 \%$ significance level.

\section{Statistical analysis}

To calculate the statistical significance between two groups, experimental results were subjected to unpaired student's $t$-test using online statistical software GraphPad Prism v5.01 (http://www.graphpad.com/quickcalcs/ttest1.cfm) and two-way ANOVA was performed for more than two groups using SPSS software (version16.0; SPSS, Chicago, IL, USA). A p-value of less than 0.05 was considered statistically significant.

\section{Results}

The auxotrophic mutant of the wild-type S01 was named as LAT9. The mutant strain (LAT9) was characterized for the phenotypic variation exhibited from the wild-type strain and was checked for its attributes in cell line model system.

\section{Phenotypic variation exhibited by the amino acid auxotrophs}

The LAT9 strain did not grow in minimal media without any additional supplement of the amino acids. However, it showed slight growth on minimal media with amino acids supplements (Fig. 1). The mutant strain has shown good growth when grown on complete media which served as a control. These results further indicate that the mutant strain has become auxotrophic to certain growth requirements which are essential for its growth. The wild-type strain was served as the positive control.

\section{Morphological variations in the mutant strain}

LAT9 differed from S01 when grown on non-selective agar medium. The colonies of S01 appeared as circular and few were irregular, large, raised, and slimy in nature whereas the LAT9 appeared as small sized colonies. The experiment was performed in triplicates and the results were found to be persistent (Fig. 2).

\section{Motility test}

Motility was observed visually by diffused growth spreading from the line of inoculation. At $4 \mathrm{~h}$ post incubation, S01 showed growth around the stab line whereas LAT9 did not show any growth. After an overnight incubation of both the tubes at $37^{\circ} \mathrm{C}$, SO1 showed diffused and thick growth throughout the medium while LAT9 diffused in an irregular fashion with less turbid growth (Fig. 3).

\section{Growth kinetics}


Growth kinetics of LAT9 was slower than S01 and it was statistically significant with a $p$-value of $>0.001$. The lag phase was $>2$ times than S01 when evaluated under the similar culture conditions. The culture density of LAT9 was found to be lesser than that of S01 when measured the absorbance at $600 \mathrm{~nm}$ spectrometrically until $30 \mathrm{~h}$. Thus, the difference in the growth pattern was clearly observed among two strains (Fig. 4).

\section{Detection of biofilm formation}

The biofilm formation was assessed for both S01 and LAT9. The former strain showed a strong biofilm formation (OD of 0.513) whereas the latter strain showed no biofilm formation (OD of 0.1). This result indicates that auxotrophic mutant has lost its biofilm forming ability. In addition, the calcoflour stained images showed that biofilm forming ability was hindered in LAT9 whereas S01 displayed strong biofilm formation (Jazeela et al. 2020).

\section{Epithelial cell invasion and intracellular replication assay}

The epithelial cell invasion by LAT9 was markedly high (1.6-fold higher in HeLa and 3.3-fold higher in HEK-293 cell lines) when compared to the S01. There was a significant difference ( $p$-value $>0.001)$ between the strains in the bacterial count recovered at $2 \mathrm{hpi} \mathrm{(Fig.} 5 \mathrm{a}$ and 5b). In contrast to the invasion ability of LAT9 in epithelial cell lines, intracellular replication of LAT9 was evidently decreased and slower than SO1 (Fig. 5c and 5d). Invasion by the Salmonella strains (S01 and LAT9) is necessary to cause infection since it is an intracellular bacterium. This data indicates that invasiveness is unaffected in auxotrophic mutant. Although the invasion of LAT9 was higher than S01, reduction in the multiplication of the former strain in the epithelial cell lines may be due to the slow growth rate of LAT9.

\section{Determination of cytotoxicity assay in HEK-293 and HeLa cell lines using SO1 and LAT9 strains}

Overall, the cytotoxicity potential of both S01 and LAT9 was higher in HEK-293 cell line than HeLa cell line. At 20 hpi, SO1 and LAT9 have shown 100 \% cell death in HEK-293 cell line whereas, HeLa cells attained $100 \%$ cell lysis at $22 \mathrm{hpi}$ of SO1 and at $24 \mathrm{hpi}$ of LAT9 respectively. In HEK-293 cell line, there was a gradual rise of cytotoxicity caused by S01 from 0-16 h and a drastic increase in the percentage of cell death was seen from 16$18 \mathrm{~h}$ whereas in HeLa cell line, there was a variation in the trend of cell death percentage obtained from 0-18 hpi of both S01 and LAT9 cells for unknown reasons. Additionally, there was an observable difference in the cytotoxicity produced by LAT9 at 6 hpi in HeLa cell line when compared to HEK-293 cell line.

\section{Expression of cytokine genes via bacterial infection on epithelial cell lines}

In HeLa cell line, an upsurge of TNF-a was observed post LAT9 infection at all the time points except at 2 hpi (Fig. S(a)) whereas in HEK-293 cell line, there was downregulation of TNF- $a$ at all the time points tested (Fig. $S(a)$ ). In addition, other proinflammatory cytokine genes such as IL-1ß and IL-6 also showed downregulation post LAT9 infection in HEK-293 cell line (Fig. S(c) and S(e)). Similar expression pattern of TNF- $a$ and IL-1ß was observed in HeLa cell line post S01 infection at all the time points (Fig. S(b) and S(d)). Furthermore, LAT9 infected HeLa cell line showed similar expression pattern of TNF- $a$ and $I L-1 ß$ genes at all the time points (Fig. S(a) and S(c)) (Table 3). 
Likewise, all the target cytokine genes like TNF- $a, I L-1 ß, I L-6, I L-10$ and TGF- $ß$ were supressed in both HEK-293 and HeLa cell lines at $6^{\text {th }}$ hpi of SO1 (Fig. (b), S(d), S(f), S(h) and S(j)) and also at $6^{\text {th }}$ hpi of LAT9 in HEK-293 cell line (Fig. S(a), S(c), S(e), S(g) and S(i)) (Table 3).

On the other hand, the expression of TGF- 3 was found to be downregulated in HeLa cell line infected with SO1 (Fig. S(j)) and LAT9 strains (Fig. S(i)) at all the time points tested. However, TGF-ß had expressed in HEK-293 cell line at 2 hpi of SO1 (Fig. S(j)) and also at 2 and 4 hpi of LAT9 (Fig. S(i)). Downregulation of TGF- $\beta$ was observed at $6^{\text {th }}$ hpi of LAT9 and SO1 on HEK-293 and HeLa cell lines (Fig. S(i) and S(j)) (Table 3).

Another anti-inflammatory cytokine, IL-10 was downregulated in HeLa and HEK-293 cell lines when analysed at $2^{\text {nd }}$ hpi and $6^{\text {th }}$ hpi of S01 (Fig. S(h) and LAT9 (Fig. S(g)) (Table 3). However, the expression level of IL-10 for S01 and LAT9 showed a similar pattern when analysed at similar time intervals in HEK-293 as well as in HeLa cell lines.

The pattern of IL-6 expression varied unlike other cytokine genes targeted in the study. In HeLa cell line, the IL-6 was expressed during initial period ( $2^{\text {nd }}$ and $4^{\text {th }} \mathrm{hpi}$ ) of SO1 but it was repressed when analysed at $6^{\text {th }} \mathrm{hpi}$ (Fig. $S(f)$ ). In HEK-293 cell line, the IL- 6 showed variation in the expression pattern post S01 infection (Fig. S(f)). Moreover, the LAT9 suppressed the expression of IL-6 at all the time points on HEK-293 as well as on HeLa cell lines (Fig. S(e)) (Table 3).

\section{Quantifying the expression of invasion genes post bacterial infection by real-time PCR}

The relative mRNA expression of the SPI-1 (invA, sipA and $\operatorname{sip} C$ ) and SPI-2 (ssrB, ssaB and sseC) genes compared to the housekeeping gene, icdA was determined at $6 \mathrm{hpi}$ of SO1 and LAT9 in two different epithelial cell lines (HEK-293 and HeLa) which was compared with the control (bacteria infected to cell lines at zero hour). Each primer was standardized with a single peak in the melt curve and optimized at $100 \mathrm{nM}$ concentration, before carrying out the expression studies using real time PCR. In HEK-293 cell line, the expression of SPI-I and SPI-II genes used in this study has shown upregulation except for sseC when analyzed at 6 hpi of both SO1 and LAT9. However, at similar condition, these genes showed variation in the expression pattern in HeLa cell line infected with SO1 and LAT9 strains. In HeLa cell line, the expression of sseC gene was downregulated post infection of S01and LAT9 which is comparable to HEK-293 cell infected bacterial strains. The invasion gene, invA showed upregulation in HeLa cell line infected with LAT9 strain whereas it downregulated in SO1 infected HeLa cells at $6 \mathrm{hpi}$. The genes $\operatorname{sip} A$ and $s s a B$ showed downregulation in HeLa cell line infected with the SO1 and LAT9 strains but in HEK-293 cell line, all the genes were upregulated (invA: 5.976-fold more by SO1 than LAT9, sipA: 1.572-fold more by S01 than LAT9, sipC. 2.604-fold more by LAT9 than S01, ssaB: 0.446-fold more by LAT9 than SO1 and ssrB: 1.06-fold more by LAT9 than S01) except for SseC in similar conditions. In HeLa cell line, the sip $C$ gene showed upregulation when infected with S01 whereas, downregulation was observed after LAT9 infection. Overall, except invA gene, the expression of $\operatorname{sip} A$, $\operatorname{sip} C$, ssaB, ssr $B$ and $\operatorname{sse} C$ was downregulated at 6 hpi of LAT9 strain in HeLa cell line whereas all the above virulence genes were found to be upregulated in HEK-293 cell line except sseC. The two genes, $\operatorname{sip} C$ and $s s r B$ were upregulated after the infection of the S01 both in HEK-293 and HeLa cell lines. Furthermore, sipA and ssaB genes showed downregulation in HeLa cell line post infection of SO1 and LAT9 strains unlike the expression pattern of these 2 genes in HEK-293 cell line where in upregulation was observed (Fig. 6a and 6b). 


\section{Discussion}

The major constraint in the cancer therapeutics is the inability of the therapeutic agents to distinguish the cancer cells from the normal cells. Therefore, contemporary methods are exploited on developing anti-cancer agents that target only cancer cells by sparing normal cells to avail progress in the cancer treatment. The nontyphoidal serovar of Salmonella was explored in this study for its tumor targeting potential in vitro via the expression of certain proinflammatory cytokine genes in epithelial cell lines. In the recent years, the nontyphoidal Salmonella serovars were utilized in cancer therapeutics due to its unique potential to target and accumulate inside the small and large metastatic tumors (Hoffman 2016). Several studies have carried out to check the potential of Salmonella Typhimurium (VP20009) in eradicating the tumor after modifying it by genetic engineering technology (Arrach et al. 2010; Hiroshima et al. 2013; Zheng et al. 2017). However, this study is the first of its kind wherein the ability of laboratory generated auxotrophic mutant NTS strain of Salmonella Oslo (LAT9) was checked for the production of cytokine genes in cell line model post bacterial infection.

The mutant strain (LAT9) exhibited change in phenotypic characters such as variation in morphology, growth curve, biofilm formation etc. Previous findings such as the study of Gwee et al. 2019 showed that growth defect was observed in an auxotrophic mutant when grown in minimal media, but the growth was restored when amino acids such as leucine and arginine was supplied (Gwee et al. 2019). Similarly, in the present study, the LAT9 strain did not show any growth when it was streaked on minimal media but slow and slight growth was observed when the growth media was supplemented with amino acids leucine and arginine which is also in accordance with the study of Lv et al. 2015 wherein they showed the growth of mutant phenotypes of Natrinema species which was auxotrophic to leucine, lysine and arginine grew on minimal medium with the nutritional supplements (Lv et al. 2015). In addition, growth defect of LAT9 in the minimal media was cured when the bacteria was grown on a complete media. Therefore, LAT9 was further examined for other phenotypic characteristics. Morphologically, the LAT9 appeared small in size (approximately 1:10) when compared with S01 after plating the strain on a non-selective agar media (Fig. 2) which was comparable with the study of Lv et al. 2015 wherein the amino acid auxotrophs of haloarchean generated showed small sized colonies on minimal media supplied with the relevant amino acids (Kwan et al. 2015).

In terms of growth rate, the mutant showed significant reduction in the initial lag phase as well as in the overall growth in comparison with the parent strain, S01. A study using auxotrophic mutant of Salmonella enterica conducted by Kwan et al. 2015 found that phenotypic growth and metabolism of amino acid auxotrophs was influenced by the uniqueness of each nutrient and they concluded the necessity of production of certain amino acids by this bacterium by itself since nutrients regulate its growth (Kwan et al. 2015). They also proved that interruption of amino acid pathways decreased the load of mutant Salmonella enterica recovered from the spermosphere and early rhizosphere of alfalfa seedlings when compared to the wild-type bacteria (Kwan et al. 2015). In addition, a study of Gordhan et al. 2002 demonstrated that L-arginine auxotrophic mutant of Mycobacterium tuberculosis showed decline in the growth rate upto undetectable level post 14 days of inoculation in the culture from $10^{6} \mathrm{CFU} / \mathrm{mL}$ when assessed in the growth medium (Middlebrook $7 \mathrm{H} 9$ medium) without the supplements of amino acid arginine when compared to wild-type bacteria, but it has reached to stationary phase with an optical density similar to the wild-type in the medium containing the maximum amino acid supplement although it showed a delayed lag phase (Gordhan et al. 2002). Therefore, with respect to growth kinetic study of mutant and wild-type strains, our study showed similarity to the study of Gordhan et al. 
2002 (Gordhan et al. 2002). Previous in vitro study carried out using Salmonella Typhimurium harbouring aro $A$ mutation was found to be less motile than the parent strain, however the negative staining results of electron microscopy revealed the presence of flagella in both the strains although the mutant had impaired motility (Felgner et al. 2016). Hence, the motility test carried out in the present study revealed that the strain LAT9 was comparatively less motile than S01. Therefore, we assume that the alteration in the growth rate of LAT9 must have resulted in its lower motility. In addition to all these tests, the mutant was also subjected for its biofilm forming ability, wherein it revealed that the wild-type Salmonella is a strong biofilm former whereas the LAT9 strain has lost its ability to form biofilm. The alteration in the biofilm forming ability might be due to the mutation in the genes that affected its growth rate, motility and caused other phenotypic defects (Chorobik et al. 2013). However, this needs further investigation in our study.

Since, Salmonella is an intra-cellular pathogen and its invasion is a dynamic phase to produce the oncolytic activity (Kim et al. 2015), we evaluated the invasion and replication potential of the mutant strain. The mutant strain showed significantly higher invasiveness (1.67-fold > by LAT9 than S01) than wild- type strain in vitro in the epithelial cell lines tested while its replication was significantly reduced than the SO1 (Fig.5). Similar results were observed in a study conducted by Zhao et al. 2006 wherein they showed that S. Typhimurium A1-R mutant Leu-Arg auxotroph could efficiently invade HT-29 tumour cells (Zhao et al. 2006). Moreover, the lower replication rate may be due to its slower growth rate which is in comparable to the study of Felgner et al. 2016 wherein they found that aroA deletion mutant exhibited lower replication in $\mathbf{J 7 7 4}$ cell line (macrophage like cell line) whereas replication of the wild-type strain was more (Felgner et al. 2016).

In order to determine the cytotoxicity of the auxotrophic mutant in the cell line model system, we have administered bacterial strains of wild-type and mutant to HeLa and HEK-293 cell lines at an m.o.i. of 10 and monitored the cytotoxic potential of the bacterial strains from 0-24 $\mathrm{h}$ by performing LDH assay for all the time points of infection at an interval of an hour. Cent percent cytotoxicity was attained at $18^{\text {th }}$ hour post LAT9 and S01 infection in HEK-293 cell line whereas in HeLa cell line complete cell death was observed in between $22^{\text {nd }}$ and $24^{\text {th }}$ hour of bacterial infection. Thus, from these results we assumed that cytotoxicity of the bacterial strains varied in cell lines at different time points. Although, there was a variation in the trend of cell death at different time intervals in these two cell lines, the auxotrophic mutant retained the cytotoxic potential similar to the wild-type strain. A previous study demonstrated the histological analysis for cytototoxic potential of the Salmonella Typhimurium in inducing necrosis of tumor and causing apoptosis wherein they hypothised that these mechanisms might be as result of the triggering of TNF-alpha by Salmonella Typhimurium (Leschner et al. 2009). Consequently, the damage caused to the normal cell by the Salmonella Typhimurium would be less because of the its ability to lyse the tumor cells from within (Westphal et al. 2008). Therefore, it suggests that bacteria club together mostly in the immunity confined region and not in the external layer of tumor tissue where tumor cells multiply (Chen et al. 2015). Hence, in this study we assume that auxotrophic mutant (LAT9) might selectively target tumor cells in the higher animal model system since it causes lysis of tumor cells.

As the expression of proinflammatory cytokines plays a very important role in tumor regression, both LAT9 and S01 strains were checked for its ability to trigger cytokine response by determining the expression of cytokine genes in HEK-293 and HeLa cell lines at different time intervals after exposure. Tumor Necrosis Factor-alpha (TNF-a) plays as a key arbitrator in bacteria mediated tumor therapy. Upon systemic infection of the bacteria, necrosis is triggered by TNF-a in tumor tissues (Felgner et al. 2018;Jia et al. 2020). At the time of tumor lysis,

Page $11 / 27$ 
cytokines such as Interleukin-1 beta (IL-1ß) and TNF-a plays a crucial role (Phan et al. 2015; Zheng et al. 2017). In the present study, TNF- $a$ and IL-1ß were expressed at 6 hpi of LAT9 on HeLa cells (Fig. S(a) and S(c)). This observation is similar to the study of Kim et al. 2015 wherein they proved that Salmonella infection lead to increased infiltration of pro-inflammatory cytokines such as IL-1ß and TNF-a that lead to tumor destruction. Apoptosis was induced by TNF-a and T-cells (involved in innate and adaptive immune system) that lead to tumor cell lysis (Kim et al. 2015). Felgner et al. 2018 also revealed the elevated levels of TNF-a in the tumors infected with SF200 (Felgner et al. 2018). Similar to earlier studies, this study also showed the production of cytokine genes such as TNF- $a$ and $I L-1 ß$ that leads to the death of cancer cell lines at 6 hpi of LAT9.

In addition, Interleukin-1 beta (IL-10) and Tumor Growth Factor-beta (TGF-ß) were downregulated in HeLa cell line when analysed at 6 hpi of LAT9 (Fig. S(g) and S(i)), this data is in agreement with a study carried out using Listeria monocytogenes which was analysed for its tumor inhibiting ability wherein they showed the reduction in the cytokines such as IL-10 and TGF- $ß$ and the activation of IL-2, IL-6, IL-12, and TNF-a during immunostimulation in tumor microenvironment (Masjedi et al. 2018, Ebbing et al. 2019). TGF-ß is known to orchestrate the cancer cell progressions during the late stage by the induction of mesenchymal phenotype in the epithelial tumors, a process where epithelial to mesenchymal transition (EMT) occurs (Löffek 2018).

Furthermore, Loffek 2018, revealed that tumor patients had advantageous effect when TGF-ß was blockaded and hence, it caused offset of tumor relapses (Löffek 2018). Consequently, the preclinical studies carried out in mouse models found the reduction in the advancement of recognised osteolytic lesions and also the reduced progression of melanoma bone metastasis after targeting the TGF- $\beta$ therapeutically (Mohammad et al. 2011). Tumor growth was decreased in B16F0 melanomas and augmentation of the antitumor immunity was observed in C57BL/ 6 mice when the TGF- $ß$ was silenced (Tai and Wang 2013). The plasma levels of TGF- $\beta$ was increased in patients with renal cell carcinoma, colon cancer, breast cancer and melanoma which resulted in poor clinical outcome besides the development of metastasis and the advancement of tumor. Therefore, many in vitro and in vivo studies demonstrated the clinical stand point for the hindrance of TGF- $\beta$ signalling in cancer treatment (Wikström et al 1998; Junker et al. 1996; Shariat et al. 2002; Reiss and Barcellos-Hoff 1997). Thus, a decrease or downregulation of TGF-ß on LAT9 exposure in our study shows that the mutant strain (LAT9) might replicate the same results in higher animal models and could become a candidate strain to be used for anticancer therapy in the future.

The role of IL-10 was associated with the production of immune suppressive tumor microenvironment (O'Garra and Vieira 2007). Interleukin-10 also hinders the secretion of proinflammatory cytokines like TNF-a, IL-1ß, IL-6, IFN-gamma etc. by CD4 ${ }^{+}$T-cells in vitro (Moore et al. 2001;Mumm et al. 2011). Therefore, in this study we have observed the reduced expression of IL-10 and increased expression of TNF-a at 6 hpi on HeLa cell line. This might result in tumor cell regression in higher animal models.

Interleukin-6 (IL-6) is a pro-inflammatory cytokine produced by different cell types such as helper T (Th) cells, tumor associated macrophages (TAMs), myeloid-derived suppressor cells (MDSCs) and fibroblasts in the tumor microenvironment including tumor cells which plays a crucial role in progression and differentiation of cancer cells (Moore et al. 2001; Bromberg and Wang 2009;Phan et al. 2015). In several types of cancer, elevated levels of IL- 6 has been validated inside the tumor site and also in serum which thereby resulted in poor prognosis and reduced life span of the patients whereas better treatment response was achieved as a result of decline in the IL-6 level (Grivennikov S, Karin M. 2008; Guo et al. 2012; Dethlefsen et al. 2013; Shibayama et al. 2014) The 
characteristic features of the tumor cell such as apoptosis, proliferation, metabolism, angiogenesis, survival, and metastasis can be exaggerated by IL-6 (Kumari et al. 2016). Resistance caused to tumor therapy such as multi drug resistance is also modulated by IL-6 (Ghandadi and Sahebkar 2006). Study carried out using LAT9 showed down regulation of IL-6 at all the time points except at $4 \mathrm{hpi}$ in HeLa cell line (Fig. S(e)) which is in contrast to many previous studies wherein they found the high concentration of IL-6 in the tumor microenvironment and its association in cancer progression. These results showed that LAT9 inhibited the propagation of HeLa cell line by the recruitment of certain proinflammatory cytokines and by inhibiting tumor promoting cytokine genes in the tumor cells at specific time point there by displaying the features of a potential agent that might inhibit the growth of tumor cells in higher animal models.

Meanwhile, all the above cytokine genes were downregulated in HEK-293 cell line at 6 hpi of LAT9. The expression of the above cytokine genes were also analysed at 3 more different time points $v i z 2 \mathrm{~h}$ and $4 \mathrm{~h}$ post LAT9 infection to HeLa and HEK-293 cell lines. At all these time points, TGF-ß showed downregulation (Fig. S(i)) whereas TNF- $\alpha$ and IL-1ß showed upregulation from $4 \mathrm{~h}$ post LAT9 infection on HeLa cell line (Fig. S(a) and S(c)). Similar experiments were carried out using SO1 on HEK-293 and HeLa cell lines in order to compare the difference in the expression of cytokine genes. Contrasting results were obtained at 6 hpi of SO1 on HEK-293 and HeLa cell lines when compared to LAT9 infection. All the cytokine genes were downregulated in both the cell lines at 6 hpi of SO1 and the results were extreme but it is to some extent comparable to the expression shown at $2 \mathrm{hpi}$ of LAT9 on HEK-293 and HeLa cell lines except for TGF- 3 where in it was upregulated in HEK293 cell line at 2 hpi of LAT9. However, the expression of TGF-ß post S01 infection in HeLa cell line showed similar trend to that obtained as a result of LAT9 infection wherein it was downregulated at all the time points tested (Fig. $S(i)$ and $S(j)$ ). Hence, the results obtained in this study suggests that at different time of bacterial infection onto HeLa and HEK-293 cell lines, the expression of cytokine genes varied considerably in either of the cell lines except for few cytokine genes. Encouraging results were obtained at $6^{\text {th }}$ hpi of LAT9 on HeLa cell line. Therefore, the virulence nature of the LAT9 at $6 \mathrm{hpi}$ was analysed by performing expression studies targeting SPI-1 and SPI-2 genes and also compared it with the virulence of SO1 on both HEK-293 and HeLa cell lines.

In order to find the virulence nature of the LAT9 strain when compared to SO1, virulence genes (invA, sipA, $\operatorname{sipC}$, $s s a B, s s r B$ and $s s e C$ ) of Salmonella Pathogenecity Islands one and two (SPI-1 and SPI-2) which aid in bacterial cell invasion and intracellular replication were selected to check the expression level in the epithelial cell lines, HEK-293 and HeLa respectively. All the virulence genes tested showed upregulation at 6 hpi of SO1 and LAT9 strains in HEK-293 cell line except sseC gene (Fig. 6b), which showed down regulation in both the strains. However, variable results were seen in HeLa cell line infected with LAT9 and SO1 (Fig. 6a). At 6 hpi of LAT9 on HeLa cell lines, all the virulence genes showed downregulation except invA whereas only sipC and ssrB showed its expression after $\mathrm{SO} 1$ infection. When the virulence genes expression was compared between the epithelial cell lines after the infection of LAT9, all the genes were found to be downregulated except invA gene in HeLa cell line whereas all the genes were upregulated except $s s e C$ in HEK-293 cell line. Likewise, SO1 also showed upregulation of all the virulence genes except $s s e C$ in HEK-293 cell line (Fig. 6b). Thus, at similar condition both wild-type and the mutant strain expressed the virulence genes in similar fashion in HEK-293 cell line but its expression in HeLa cell lines varied between the bacterial strains considerably. This is in agreement with the study of Gwee et al. (2019) wherein they showed that though the growth of auxotrophic mutant of the $S$. Agona was defective, the invasiveness of the strain was unaffected in vitro (Gwee et al. 2019). 
From the above results, we can infer that at 6 hpi of LAT9 on HeLa cell line showed less virulence compared to S01 but retained its invasion potential and it is comparable with the results obtained for epithelial cell invasion of LAT9 (Fig. 5a and 5b) wherein it showed higher invasion than S01. This signifies that the mutant NTS (LAT9) possess the ability to trigger cytokine gene expression thereby gained immunogenicity along with simultaneous reduction of its virulence property. Therefore, from this study we have observed that LAT9 has the favourable positive attributes of a therapeutic agent which is responsible to eradicate the expansion of cancer cells. However, protein level validation of the cytokines, mechanism of regulation of cytokines and in vivo studies are necessary to confirm the antitumor properties of LAT9.

\section{Conclusion}

The study sheds light on the positive attributes of non-typhoidal Salmonella serovar to be used as an anticancer agent in higher animal models in future studies. The auxotrophic mutant characterised in the study triggered the expression of proinflammatory cytokine genes such as $T N F-a$ and $I L-1 \beta$ in cell line model that otherwise plays a very important role in tumor regression. Furthermore, the mutant strain showed lower virulence, but it retained higher invasion potential which is regarded as the positive feature of an ideal tumoricidal bacterial agent. To the best of our knowledge, this is the first study carried out using a less pathogenic strain of NTS, Salmonella Oslo in order to explore its positive effects in combating the cancer cells effectively via the activation of certain cytokine genes and thus, aiming to replicate similar results in animal models. Though a preliminary study, it tried to unravel the potential of a less pathogenic microbe which can be utilized in clinical application in a near future in order to combat tumors. Hence, the finding of this study is an important step towards the clinical application. Nevertheless, the application of the attenuated Salmonella Oslo generated in the present study needs further investigation in vivo animal models to be successfully used as an anticancer agent.

\section{Declarations}

\section{Acknowledgement}

The financial support received for this study from Nitte (Deemed to be University) in the form of an intramural grant (NUFR1/2016/19-04) and the whole genome work carried out at Dr. Seamus Fanning's Laboratory, Centre for food safety and zoonoses, Dublin is gratefully acknowledged

\section{Conflict of interest}

The authors have no financial conflict of interest to declare

\section{References}

1. Adkins I, Holubova J, Kosova M, Sadilkova L (2012) Bacteria and their toxins tamed for immunotherapy. Curr Pharm Biotechnol 13:1446-73.

2. Arrach N, Cheng P, Zhao M, Santiviago CA, Hoffman RM, McClelland M (2010) High-throughput screening for Salmonella avirulent mutants that retain targeting of solid tumors. Cancer Res 70:2165-70.

3. Ashu EE, Xu J, Yuan ZC (2019) Bacteria in cancer therapeutics: a framework for effective therapeutic bacterial screening and identification. J Cancer 10:1781. 
4. Bhowmick PP, Devegowda D, Ruwandeepika HD, Fuchs TM, Srikumar S, Karunasagar I, Karunasagar I (2011) gcpA (stm1987) is critical for cellulose production and biofilm formation on polystyrene surface by Salmonella enterica serovar Weltevreden in both high and low nutrient medium. Microb Pathog 50:114-22.

5. Bhunia AK, Steele PJ, Westbrook DG, Bly LA, Maloney TP, Johnson MG (1994) A six-hour in vitro virulence assay for Listeria monocytogenes using myeloma and hybridoma cells from murine and human sources. Microb Pathog 16:99-110.

6. Blanc-Potard AB, Groisman EA (1997) The Salmonella selC locus contains a pathogenicity island mediating intramacrophage survival. EMBO J 16:5376-85.

7. Bromberg J, Wang TC (2009) Inflammation and cancer: IL-6 and STAT3 complete the link. Cancer Cell 15:79-80.

8. Chen JQ, Zhan YF, Wang W, Jiang SN, Li XY (2015) The engineered Salmonella typhimurium inhibits tumorigenesis in advanced glioma. Onco Targets Ther 8:2555.

9. Chorobik P, Czaplicki D, Ossysek K, Bereta J (2013) Salmonella and cancer: from pathogens to therapeutics. Acta Biochim Pol 60(3).

10. Crull K, Bumann D, Weiss S (2011) Influence of infection route and virulence factors on colonization of solid tumors by Salmonella enterica serovar Typhimurium. FEMS Immunol Med Microbiol 62:75-83.

11. Dethlefsen C, Højfeldt G, Hojman P (2013) The role of intratumoral and systemic IL-6 in breast cancer. Breast Cancer Res Treat 138:657-64.

12. Ebbing EA, van der Zalm AP, Steins A, Creemers A, Hermsen S, Rentenaar R, Klein M, Waasdorp C, Hooijer GK, Meijer SL, Krishnadath KK (2019) Stromal-derived interleukin 6 drives epithelial-to-mesenchymal transition and therapy resistance in esophageal adenocarcinoma. PNAS 116:2237-42.

13. Felgner S, Frahm M, Kocijancic D, Rohde M, Eckweiler D, Bielecka A, Bueno E, Cava F, Abraham WR, Curtiss R, Häussler S (2016) aroA-deficient Salmonella enterica serovar Typhimurium is more than a metabolically attenuated mutant. MBio 7(5).

14. Felgner S, Kocijancic D, Frahm M, Heise U, Rohde M, Zimmermann K, Falk C, Erhardt M, Weiss S (2018) Engineered Salmonella enterica serovar Typhimurium overcomes limitations of anti-bacterial immunity in bacteria-mediated tumor therapy. Oncoimmunology 7:e1382791.

15. Freeman JA, OhI ME, Miller SI (2003) The Salmonella enterica serovar typhimurium translocated effectors SseJ and SifB are targeted to the Salmonella-containing vacuole. Infect Immun 71:418-27.

16. Ghandadi M, Sahebkar A (2006) Interleukin-6: a critical cytokine in cancer multidrug resistance. Curr Pharm Des 22:518-26.

17. Giribaldi G, Prato M, Ulliers D, Gallo V, Schwarzer E, Akide-Ndunge OB, Valente E, Saviozzi S, Calogero RA, Arese $P$ (2010) Involvement of inflammatory chemokines in survival of human monocytes fed with malarial pigment. Infect Immun78:4912-21.

18. Gordhan BG, Smith DA, Alderton H, McAdam RA, Bancroft GJ, Mizrahi V (2002) Construction and phenotypic characterization of an auxotrophic mutant of Mycobacterium tuberculosis defective in Larginine biosynthesis. Infect Immun 70:3080-4.

19. Grivennikov S, Karin M (2008) Autocrine IL-6 signaling: a key event in tumorigenesis? Cancer Cell 13:7-9. 20. Guo Y, Xu F, Lu T, Duan Z, Zhang Z (2012) Interleukin-6 signaling pathway in targeted therapy for cancer. Cancer Treat 38:904-10. 
21. Gwee CP, Khoo CH, Yeap SK, Tan GC, Cheah YK (2019) Targeted inactivation of Salmonella Agona metabolic genes by group II introns and in vivo assessment of pathogenicity and anti-tumour activity in mouse model. PeerJ 7:e5989.

22. Hiroshima Y, Zhao M, Zhang Y, Maawy A, Hassanein M, Uehara F, Miwa S, Yano S, Momiyama M, Suetsugu A, Chishima T (2013) Comparison of efficacy of Salmonella typhimurium A1-R and chemotherapy on stemlike and non-stem human pancreatic cancer cells. Cell Cycle 12:2774-80.

23. Hoffman RM (2016) Future of bacterial therapy of cancer. In Bacterial Therapy of Cancer. New York, NY: Humana Press, pp. 177-184.

24. Jazeela K, Chakraborty A, Karunasagar I, Deekshit VK (2020) Nontyphoidal Salmonella: a potential anticancer agent. J Appl Microbiol 28:2-14.

25. Jazeela K, Chakraborty A, Rai P, Kumar BK, Srikumar S, van Nguyen S, Hurley D, Fanning S, Karunasagar I, Deekshit VK (2020) Draft genome sequences of Salmonella Oslo isolated from seafood and its laboratory generated auxotrophic mutant. J Genomics 8:7.

26. Jia X, Guo J, Guo S, Zhao T, Liu X, Cheng C, Wang L, Zhang B, Meng C, Jia H, Luo E (2020) Antitumor effects and mechanisms of CpG ODN combined with attenuated Salmonella-delivered siRNAs against PD1. Int Immunopharmacol 9;90:107052.

27. Jung HC, Eckmann L, Yang SK, Panja AS, Fierer J, Morzycka-Wroblewska E, Kagnoff MF (1995) A distinct array of proinflammatory cytokines is expressed in human colon epithelial cells in response to bacterial invasion. J Clin Investig 95:55-65.

28. Junker U, Knoefel B, Nuske K, Rebstock K, Steiner T, Wunderlich H, Junker K, Reinhold D (1996) Transforming growth factor beta 1 is significantly elevated in plasma of patients suffering from renal cell carcinoma. Cytokine 8:794-8.

29. Khawar IA, Kim JH, Kuh HJ (2015) Improving drug delivery to solid tumors: priming the tumor microenvironment. J Control Release 201:78-89.

30. Kim JE, Phan TX, Nguyen VH, Dinh-Vu HV, Zheng JH, Yun M, Park SG, Hong Y, Choy HE, Szardenings M, Hwang W (2015) Salmonella typhimurium suppresses tumor growth via the pro-inflammatory cytokine interleukin-1 $\beta$. Theranostics 5:1328.

31. Kramer MG, Masner M, Ferreira FA, Hoffman RM (2018) Bacterial therapy of cancer: promises, limitations, and insights for future directions. Front Microbiol 9:16.

32. Kumari N, Dwarakanath BS, Das A, Bhatt AN (2016) Role of interleukin-6 in cancer progression and therapeutic resistance. Tumor Biol 37:11553-72.

33. Kwan G, Pisithkul T, Amador-Noguez D, Barak J (2015) De novo amino acid biosynthesis contributes to Salmonella enterica growth in alfalfa seedling exudates. Appl Environ Microbiol 81:861-73.

34. Leschner S, Westphal K, Dietrich N, Viegas N, Jablonska J, Lyszkiewicz M, Lienenklaus S, Falk W, Gekara N, Loessner H, Weiss S (2009) Tumor invasion of Salmonella enterica serovar Typhimurium is accompanied by strong hemorrhage promoted by TNF-a. PloS one 4:e6692.

35. Liu F, Zhang L, Hoffman RM, Zhao M (2010) Vessel destruction by tumor-targeting Salmonella typhimurium A1-R is enhanced by high tumor vascularity. Cell Cycle 9:4518-24.

36. Livak KJ, Schmittgen TD (2001) Analysis of relative gene expression data using real-time quantitative PCR and the 2- $\triangle \triangle C T$ method. Methods 25:402-8. 
37. Löffek S (2018) Transforming of the Tumor Microenvironment: Implications for TGF-Inhibition in the Context of Immune-Checkpoint Therapy. J Oncol

38. Lv J, Wang S, Wang Y, Huang Y, Chen X (2015) Isolation and molecular identification of auxotrophic mutants to develop a genetic manipulation system for the haloarchaeon Natrinema sp. J7-2 Archaea.

39. Maldonado Y, Fiser JC, Nakatsu CH, Bhunia AK (2005) Cytotoxicity potential and genotypic characterization of Escherichia coli isolates from environmental and food sources. App Environ Microbiol 71:1890-8.

40. Masjedi A, Hashemi V, Hojjat-Farsangi M, Ghalamfarsa G, Azizi G, Yousefi M, Jadidi-Niaragh F (2018) The significant role of interleukin- 6 and its signaling pathway in the immunopathogenesis and treatment of breast cancer. Biomed Pharmacother 108:1415-24.

41. Mehta R, Birerdinc A, Hossain N, Afendy A, Chandhoke V, Younossi Z, Baranova A. (2010). Validation of endogenous reference genes for qRT-PCR analysis of human visceral adipose samples. BMC Mol Biol 11:39.

42. Mercado-Lubo R, McCormick BA (2017) Can a nanoparticle that mimics Salmonella effectively combat tumor chemotherapy resistance? Nanomedicine 12:705-710.

43. Mohammad KS, Javelaud D, Fournier PG, Niewolna M, McKenna CR, Peng XH, Duong V, Dunn LK, Mauviel A, Guise TA (2011) TGF- $\beta$-RI kinase inhibitor SD-208 reduces the development and progression of melanoma bone metastases. Cancer Res 71:175-84.

44. Moore KW, de Waal Malefyt R, Coffman RL, O'Garra A (2001) Interleukin-10 and the interleukin-10 receptor. Annu Rev Immunol 19:683-765.

45. Mumm JB, Emmerich J, Zhang X, Chan I, Wu L, Mauze S, Blaisdell S, Basham B, Dai J, Grein J, Sheppard C (2011). IL-10 elicits IFNy-dependent tumor immune surveillance. Cancer Cell 20:781-96.

46. Nagarsheth N, Wicha MS, Zou W (2017) Chemokines in the cancer microenvironment and their relevance in cancer immunotherapy. Nat Rev Immunol 17:559.

47. O'Garra A, Vieira P. 2007. TH 1 cells control themselves by producing interleukin-10. Nat. Rev. Immunol. 7:425-8.

48. Parsons BL, Heflich RH (1997) Genotypic selection methods for the direct analysis of point mutations. Mutat Res Rev Mutat Res 387:97-121.

49. Phan TX, Nguyen VH, Duong MT, Hong Y, Choy HE, Min JJ (2015) Activation of inflammasome by attenuated Salmonella typhimurium in bacteria-mediated cancer therapy. Microbiol Immunol 59:664-75.

50. Rahn K, De Grandis SA, Clarke RC, McEwen SA, Galan JE, Ginocchio C, Curtiss lii R, Gyles CL (1992) Amplification of an invA gene sequence of Salmonella typhimurium by polymerase chain reaction as a specific method of detection of Salmonella. Mol Cell Probes 6:271-9.

51. Rakeman JL, Bonifield HR, Miller SI (1999) A HilA-independent pathway to Salmonella typhimurium invasion gene transcription. J Bacteriol 181:3096-104.

52. Reiss M, Barcellos-Hoff MH (1997) Transforming growth factor- $\beta$ in breast cancer: a working hypothesis. Breast Cancer Res Treat 45:81-95.

53. Scheiner B, Kirstein MM, Hucke F, Finkelmeier F, Schulze K, von Felden J, Koch S, Schwabl P, Hinrichs JB, Waneck F, Waidmann $O$ (2019) Programmed cell death protein-1 (PD-1)-targeted immunotherapy in advanced hepatocellular carcinoma: efficacy and safety data from an international multicentre real-world cohort. Aliment Pharmacol Ther 49:1323-33.

Page $17 / 27$ 
54. Shariat SF, Lamb DJ, Kattan MW, Nguyen C, Kim J, Beck J, Wheeler TM, Slawin KM (2002) Association of preoperative plasma levels of insulin-like growth factor I and insulin-like growth factor binding proteins-2 and-3 with prostate cancer invasion, progression, and metastasis. J Clin Oncol 20:833-41.

55. Shibayama O, Yoshiuchi K, Inagaki M, Matsuoka Y, Yoshikawa E, Sugawara Y, Akechi T, Wada N, Imoto S, Murakami K, Ogawa A (2014) Association between adjuvant regional radiotherapy and cognitive function in breast cancer patients treated with conservation therapy. Cancer Med 3:702-9.

56. Stepanović S, Ćirković I, Ranin L, S vabić-Vlahović M (2004) Biofilm formation by Salmonella spp. and Listeria monocytogenes on plastic surface. Lett Appl Microbiol 38:428-32.

57. Stordeur P, Poulin LF, Craciun L, Zhou L, Schandene L, De Lavareille A, Goriely S, Goldman M (2002) Cytokine quantification by real-time PCR. J Immunol Methods 259:55-64.

58. Tai KF, Wang CH (2013) Using Adenovirus Armed Short Hairpin RNA Targeting Transforming Growth Factor $\beta 1$ Inhibits Melanoma Growth and Metastasis in an Ex Vivo Animal Model. Ann Plast Surg 71:S75-81.

59. Torres W, Lameda V, Olivar LC, Navarro C, Fuenmayor J, Pérez A, Mindiola A, Rojas M, Martínez MS, Velasco M, Rojas J (2018) Bacteria in cancer therapy: beyond immunostimulation. J Cancer Metastasis Treat 24:4(4).

60. Toso JF, Gill VJ, Hwu P, Marincola FM, Restifo NP, Schwartzentruber DJ, Sherry RM, Topalian SL, Yang JC, Stock F, Freezer LJ (2002) Phase I study of the intravenous administration of attenuated Salmonella typhimurium to patients with metastatic melanoma. J Clin Oncol 20:142.

61. Westphal K, Leschner S, Jablonska J, Loessner H, Weiss S (2008) Containment of tumor-colonizing bacteria by host neutrophils. Cancer Res 68:2952-60.

62. Wikström P, Stattin P, Franck-Lissbrant I, Damber JE, Bergh A (1998) Transforming growth factor $\beta 1$ is associated with angiogenesis, metastasis, and poor clinical outcome in prostate cancer. The Prostate 37:19-29.

63. Xu W, Joo H, Clayton S, Dullaers M, Herve MC, Blankenship D, De La Morena MT, Balderas R, Picard C, Casanova JL, Pascual V (2012) Macrophages induce differentiation of plasma cells through CXCL10/IP10. J Exp Med 209:1813-23.

64. Zhang Y, Zhang N., Zhao M., Hoffman R.M (2015) Comparison of the selective targeting efficacy of Salmonella typhimurium A1-R and VNP20009 on the Lewis lung carcinoma in nude mice. Oncotarget 6:14625.

65. Zhao M, Yang M, Ma H, Li X, Tan X, Li S, Yang Z, Hoffman RM (2006) Targeted therapy with a Salmonella typhimurium leucine-arginine auxotroph cures orthotopic human breast tumors in nude mice. Cancer Res 66:7647-52.

66. Zheng JH, Nguyen VH, Jiang SN, Park SH, Tan W, Hong SH, Shin MG, Chung IJ, Hong Y, Bom HS, Choy HE (2017) Two-step enhanced cancer immunotherapy with engineered Salmonella typhimurium secreting heterologous flagellin. Sci Transl Med 9:376.

\section{Tables}

\section{Table 1 Primer details of cytokine genes}




\begin{tabular}{|c|c|c|c|c|}
\hline $\begin{array}{l}\text { Target } \\
\text { Genes }\end{array}$ & $\begin{array}{l}\text { Primer sequences } \\
\left(5^{\prime}-3^{\prime}\right)\end{array}$ & $\begin{array}{l}\text { Annealing } \\
\text { temperature } \\
\left({ }^{\circ} \mathrm{C}\right)\end{array}$ & $\begin{array}{l}\text { Product } \\
\text { size } \\
\text { (bp) }\end{array}$ & References \\
\hline \multirow[t]{2}{*}{$T N F-a$} & F: CCCAGGGACCTCTCTCTAATC & & & \multirow{2}{*}{$\begin{array}{l}\text { (Stordeur et al. } \\
2002 \text { ) }\end{array}$} \\
\hline & R: ATGGGCTACAGGCTTGTCACT & 55 & 84 & \\
\hline \multirow[t]{2}{*}{$I L-1 ß$} & F: ACAGATGAAGTGCTCCTTCCA & \multirow[t]{2}{*}{55} & \multirow[t]{2}{*}{73} & \multirow{2}{*}{$\begin{array}{l}\text { (Giribaldi et al. } \\
\text { 2010) }\end{array}$} \\
\hline & R: GTCGGAGATTCGTAGCTGGAT & & & \\
\hline \multirow[t]{2}{*}{$I L-6$} & F: GGTACATCCTCGACGGCATCT & \multirow[t]{2}{*}{55} & \multirow[t]{2}{*}{61} & \multirow[t]{2}{*}{ (Xu et al., 2012) } \\
\hline & R: GTGCCTCTTTGCTGCTTTCAC & & & \\
\hline \multirow[t]{2}{*}{ IL-10 } & F: CATCGATTTCTTCCCTGTGAA & \multirow[t]{2}{*}{55} & \multirow[t]{2}{*}{74} & \multirow{2}{*}{$\begin{array}{l}\text { (Stordeur et al. } \\
\text { 2002) }\end{array}$} \\
\hline & $\begin{array}{l}\text { R: } \\
\text { TCTTGGAGCTTATTAAAGGCATTC }\end{array}$ & & & \\
\hline \multirow[t]{2}{*}{$T G F-B$} & F: GCCCTGGACACCAACTATTGCT & \multirow[t]{2}{*}{55} & \multirow[t]{2}{*}{161} & \multirow[t]{2}{*}{ (Jung et al. 1995) } \\
\hline & $\begin{array}{l}\text { R: } \\
\text { AGGCTCCAAATGTAGGGGCAGG }\end{array}$ & & & \\
\hline \multirow[t]{2}{*}{$R P \|$} & F: CTTCACGGTGCTGGGCATT & \multirow[t]{2}{*}{55} & \multirow[t]{2}{*}{239} & \multirow{2}{*}{$\begin{array}{l}\text { (Mehta et al. } \\
\text { 2010) }\end{array}$} \\
\hline & R: GTGCGGCTGCTTCCATAA & & & \\
\hline
\end{tabular}

Table 2 Primer details of virulence genes 


\begin{tabular}{|c|c|c|c|c|}
\hline $\begin{array}{l}\text { Target } \\
\text { Gene }\end{array}$ & $\begin{array}{l}\text { Primer sequences } \\
\left(5^{\prime}-3^{\prime}\right)\end{array}$ & $\begin{array}{l}\text { Annealing } \\
\text { temperature } \\
\left({ }^{\circ} \mathrm{C}\right)\end{array}$ & $\begin{array}{l}\text { Product } \\
\text { size } \\
\text { (bp) }\end{array}$ & References \\
\hline \multirow[t]{2}{*}{$\operatorname{inv} A$} & F:GTGAAATTATCGCCACGTTCGGGCAA & & & \\
\hline & R: TCATCGCACCGTCAAAGGAACC & 54 & 284 & (Rahn et al. 1992) \\
\hline \multirow[t]{2}{*}{$\operatorname{sip} A$} & F: CCATTCGACTAACAGCAGCA & & & \\
\hline & R: CGTGACCACCTTTCCATCTT & 54 & 199 & This study \\
\hline \multirow[t]{2}{*}{$\operatorname{sip} C$} & F: GTACCGATGCGACGAAAAAT & & & \\
\hline & R: ATCGATTCGGGTCATATCCA & 54 & 197 & This study \\
\hline \multirow[t]{2}{*}{$s s a B$} & F: GGATTCATGCTGGCAGTTTT & & & \\
\hline & R: TGCTGCAAGCAGTAGTGTCA & 54 & 207 & This study \\
\hline \multirow[t]{2}{*}{$s s r B$} & F: AATGCCTGTTGTGCATACGA & & & \\
\hline & R: TTAGCACCTGCGGCTAAAGT & 54 & 176 & This study \\
\hline \multirow[t]{2}{*}{ ssec } & F: CAGATTGGCCGTGCTTTTAT & & & \\
\hline & R: ATTCGCCATAGCCATTTCAC & 54 & 210 & This study \\
\hline \multirow[t]{2}{*}{$i c d A$} & F:TGGTATCGGTGTTGATGTCACTC & & & \multirow{2}{*}{$\begin{array}{l}\text { (Parsons and } \\
\text { Heflich 1997) }\end{array}$} \\
\hline & R:CATCCTGGCCGTAAACCTGTGTG & 54 & 140 & \\
\hline
\end{tabular}

Table 3 Relative expression levels of cytokine genes post bacterial invasion on HEK-293 and HeLa cell lines 


\begin{tabular}{|c|c|c|c|c|c|c|c|c|c|}
\hline \multirow[t]{2}{*}{$\begin{array}{l}\text { Time } \\
\text { points }\end{array}$} & \multirow[t]{2}{*}{$\begin{array}{l}\text { Cytokine } \\
\text { genes }\end{array}$} & \multicolumn{3}{|c|}{$\begin{array}{l}\text { Relative gene } \\
\text { expression }\end{array}$} & & \multicolumn{2}{|c|}{$\begin{array}{l}\text { Relative gene } \\
\text { expression }\end{array}$} & \multirow[t]{2}{*}{ Ratio } & \multirow[b]{2}{*}{$p$-value } \\
\hline & & $\begin{array}{l}\text { LAT9 } \\
\text { on } \\
\text { HEK- } \\
293\end{array}$ & $\begin{array}{l}\text { LAT9 on } \\
\text { HeLa }\end{array}$ & Ratio & $p$-value & $\begin{array}{l}\text { SO1 on } \\
\text { HEK- } \\
293\end{array}$ & $\begin{array}{l}\text { SO1 on } \\
\text { HeLa }\end{array}$ & & \\
\hline \multirow[t]{5}{*}{$2 \mathrm{~h}$} & $T N F-a$ & $\begin{array}{l}0.069 \\
\pm \\
0.0519\end{array}$ & $\begin{array}{l}0.0916 \pm \\
0.0200\end{array}$ & 0.75 & $>0.05$ & $\begin{array}{l}27.1979 \\
\pm \\
0.9329\end{array}$ & $\begin{array}{l}72.949 \pm \\
7.4952\end{array}$ & 0.3728 & $<0.05$ \\
\hline & $T G F-\beta$ & $\begin{array}{l}2.4005 \\
\pm \\
1.3949\end{array}$ & $\begin{array}{l}0.6784 \pm \\
0.0199\end{array}$ & $\begin{array}{l}3 . \\
5384\end{array}$ & $>0.05$ & $\begin{array}{l}12.7857 \\
\pm \\
0.8141\end{array}$ & $\begin{array}{l}0.1363 \pm \\
0.0678\end{array}$ & 93.805 & $<0.05$ \\
\hline & $I L-1 \beta$ & $\begin{array}{l}0.0026 \\
\pm \\
0.0028\end{array}$ & $\begin{array}{l}0.4035 \pm \\
0.1413\end{array}$ & 0.0064 & $<0.05$ & $\begin{array}{l}0.8184 \\
\pm \\
0.2372\end{array}$ & $\begin{array}{l}4.7372 \pm \\
1.0817\end{array}$ & 0.1727 & $<0.05$ \\
\hline & IL-6 & $\begin{array}{l}0.0164 \\
\pm \\
0.0197\end{array}$ & $\begin{array}{l}0.1373 \pm \\
0.0326\end{array}$ & 0.1194 & $>0.05$ & $\begin{array}{l}0.162 \pm \\
0.0961\end{array}$ & $\begin{array}{l}5.0587 \pm \\
2.5593\end{array}$ & 0.032 & $<0.05$ \\
\hline & IL-10 & $\begin{array}{l}0.1754 \\
\pm \\
0.2056\end{array}$ & $\begin{array}{l}0.0141 \pm \\
0.0061\end{array}$ & 12.5 & $>0.05$ & $\begin{array}{l}0.3072 \\
\pm \\
0.1810\end{array}$ & $\begin{array}{l}0.2504 \pm \\
0.2044\end{array}$ & 1.2268 & $>0.05$ \\
\hline \multirow[t]{5}{*}{$4 \mathrm{~h}$} & $T N F-a$ & $\begin{array}{l}0.0492 \\
\pm \\
0.0238\end{array}$ & $\begin{array}{l}1.7254 \pm \\
0.1267\end{array}$ & 0.0285 & $<0.05$ & $\begin{array}{l}14.4427 \\
\pm \\
2.0459\end{array}$ & $\begin{array}{l}532.4358 \\
\pm 33.9021\end{array}$ & 0.0271 & $<0.05$ \\
\hline & $T G F-\beta$ & $\begin{array}{l}1.9747 \\
\pm \\
1.3642\end{array}$ & $\begin{array}{l}0.7149 \pm \\
0.2372\end{array}$ & 2.7622 & $>0.05$ & $\begin{array}{l}0.0262 \\
\pm \\
0.0158\end{array}$ & $\begin{array}{l}0.2932 \pm \\
0.2225\end{array}$ & 0.0893 & $>0.05$ \\
\hline & $I L-1 \beta$ & $\begin{array}{l}0.0168 \\
\pm \\
0.0151\end{array}$ & $\begin{array}{l}4.2247 \pm \\
0.6599\end{array}$ & 0.0039 & $<0.05$ & $\begin{array}{l}0.3198 \\
\pm 0.014\end{array}$ & $\begin{array}{l}39.1570 \\
\pm 6.8735\end{array}$ & 0.0081 & $<0.05$ \\
\hline & IL-6 & $\begin{array}{l}0.0741 \\
\pm \\
0.0489\end{array}$ & $\begin{array}{l}1.0081 \pm \\
0.4664\end{array}$ & 0.0735 & $<0.05$ & $\begin{array}{l}1.6297 \\
\pm \\
1.6674\end{array}$ & $\begin{array}{l}4.1833 \pm \\
2.5988\end{array}$ & 0.3895 & $>0.05$ \\
\hline & IL-10 & $\begin{array}{l}0.9334 \\
\pm \\
0.7296\end{array}$ & $\begin{array}{l}8.0848 \pm \\
0.1981\end{array}$ & 0.1154 & $<0.05$ & $\begin{array}{l}0.342 \pm \\
0.0748\end{array}$ & $\begin{array}{l}27.2083 \\
\pm 16.4697\end{array}$ & 0.0125 & $<0.05$ \\
\hline \multirow[t]{4}{*}{$6 \mathrm{~h}$} & $T N F-a$ & $\begin{array}{l}0.4577 \\
\pm \\
0.0847\end{array}$ & $\begin{array}{l}10.1883 \\
\pm \\
1.5914\end{array}$ & 0.0449 & $<0.05$ & $\begin{array}{l}0.3983 \\
\pm \\
0.0564\end{array}$ & $\begin{array}{l}0.6885 \pm \\
0.6507\end{array}$ & 0.5785 & $>0.05$ \\
\hline & $T G F-\beta$ & $\begin{array}{l}0.0012 \\
\pm 0\end{array}$ & $\begin{array}{l}0.4375 \\
\pm 0.1082\end{array}$ & 0.0027 & $<0.05$ & $\begin{array}{l}0.0561 \\
\pm \\
0.0235\end{array}$ & $\begin{array}{l}0.0263 \pm \\
0.0239\end{array}$ & 2.133 & $>0.05$ \\
\hline & $I L-1 \beta$ & $\begin{array}{l}0.0497 \\
\pm \\
0.018\end{array}$ & $\begin{array}{l}1.5217 \\
\pm 0.0671\end{array}$ & 0.0326 & $<0.05$ & $\begin{array}{l}0.1239 \\
\pm \\
0.0695\end{array}$ & $\begin{array}{l}0.0716 \pm \\
0.0962\end{array}$ & 1.7304 & $>0.05$ \\
\hline & IL-6 & 0.289 & 0.9328 & 0.3098 & $<0.05$ & 0.0751 & $0.0698 \pm$ & 1.0759 & $>0.05$ \\
\hline
\end{tabular}




\begin{tabular}{|c|c|c|c|c|c|c|c|c|}
\hline & $\stackrel{ \pm}{0.0325}$ & \pm 0.4957 & & & $\stackrel{ \pm}{0.0277}$ & 0.0946 & & \\
\hline IL-10 & $\begin{array}{l}0.1739 \\
\pm \\
0.011\end{array}$ & $\begin{array}{l}0.1602 \\
\pm 0.1124\end{array}$ & 1.0855 & $>0.05$ & $\begin{array}{l}0.0344 \\
\pm \\
0.0325\end{array}$ & $\begin{array}{l}0.0288 \pm \\
0.0089\end{array}$ & 1.1944 & $>0.05$ \\
\hline
\end{tabular}

Ratio: Bacterial invasion on HEK-293 to HeLa cell lines

\section{Figures}

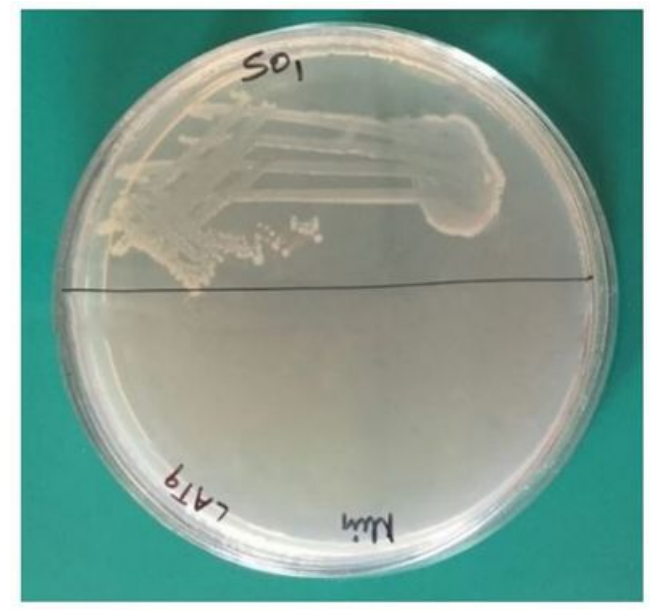

(a)

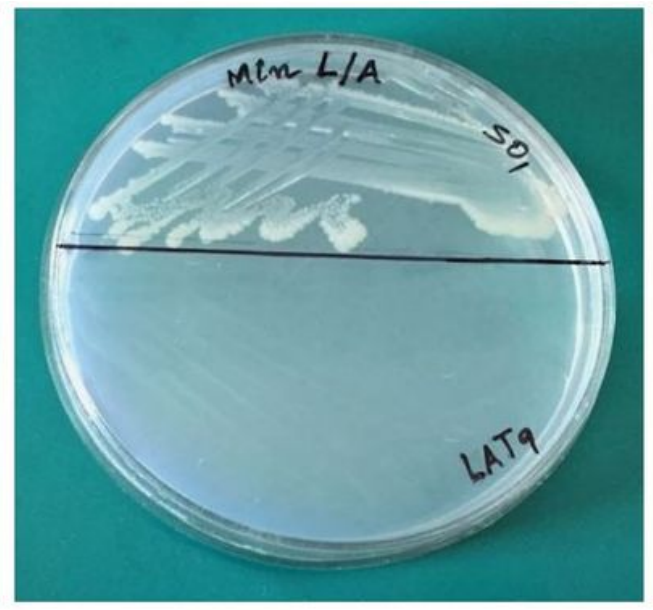

(b)

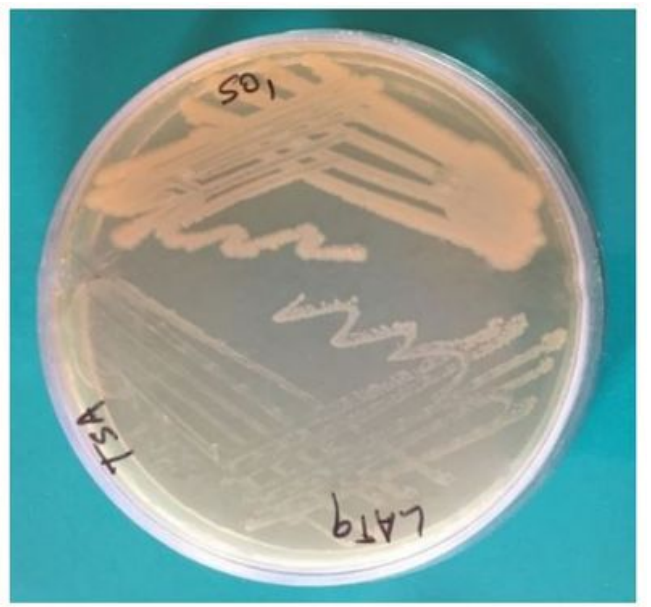

(c)

\section{Figure 1}

Representative images of the leuB/argH transformant of nontyphoidal Salmonella (NTS) obtained after electroporation of PCR-products of leuB/argH Kan cassette into electrocompetent lambda Red plasmid. Plates $A, B$ and $C$ represents the difference in the growth pattern shown by auxotrophic mutant (LAT9) and wild-type (S01) strains when streaked on minimal media without any amino acid supplements (a), minimal media supplemented with amino acids leucine and arginine (b) and on complete media (c). 
(a)

(b)

Figure 2

Appearance of wild-type (SO1) (a) and auxotrophic mutant (LAT9) (b) on LB agar media. 


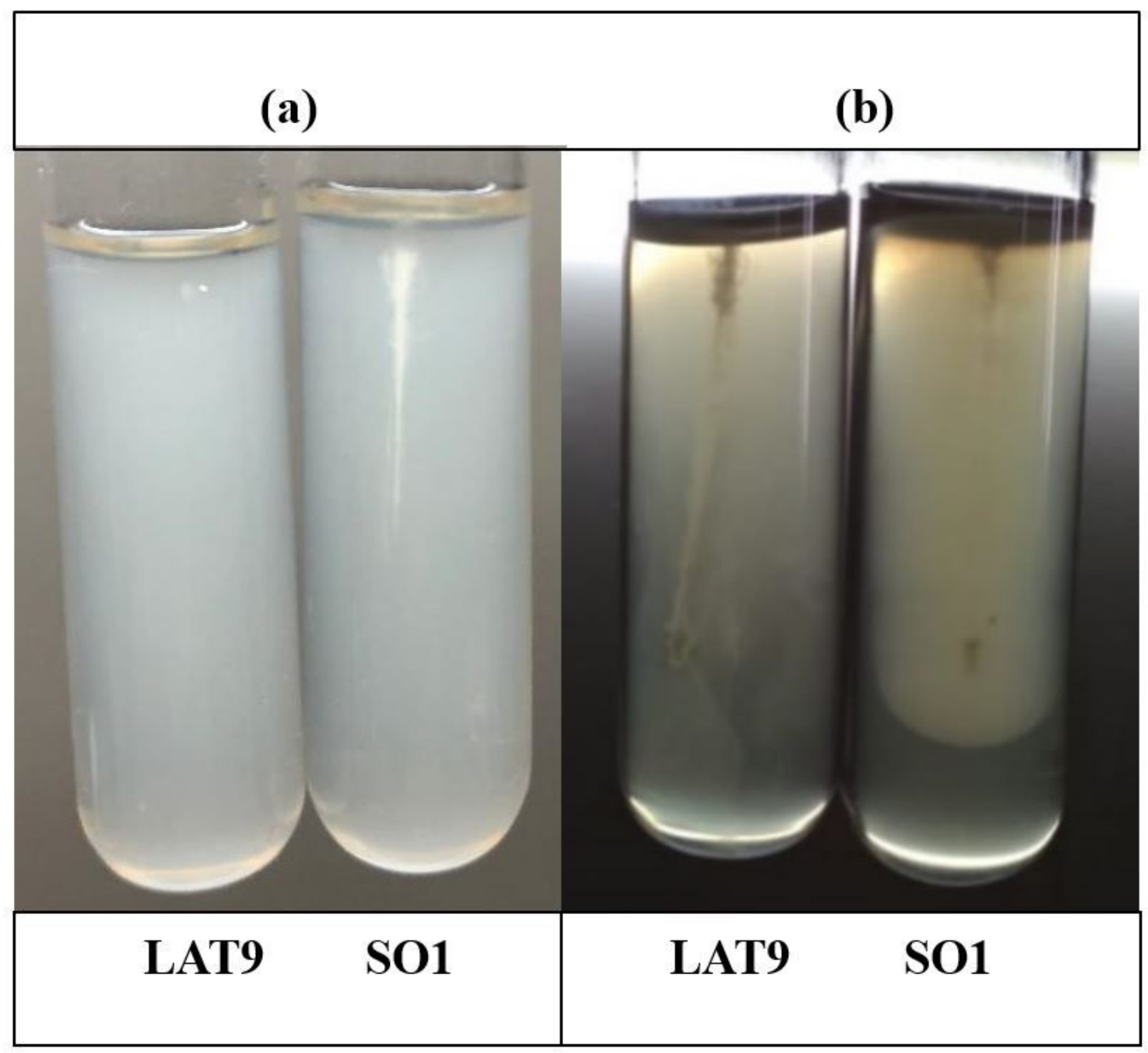

Figure 3

Auxotrophic mutant (LAT9) and wild-type (SO1) nontyphoidal Salmonella stabbed into soft agar and incubated for 4 hpi (a) and 24 hpi (b) respectively. 


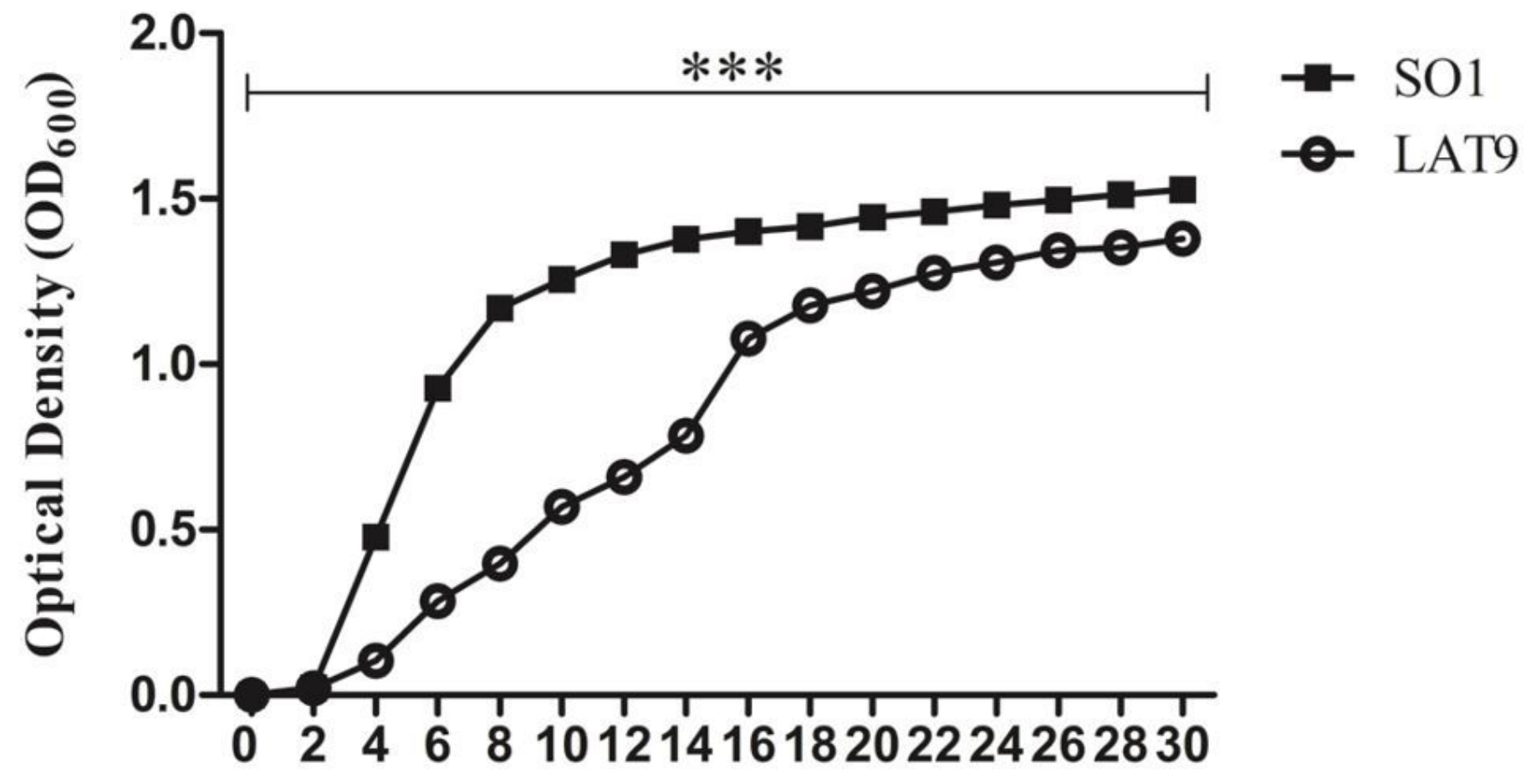

Time (h)

Figure 4

Growth kinetics of S01 and LAT9 in non-selective broth media. Growth rate of LAT9 was slower with more than $4 \mathrm{~h}$ of lag phase when compared with the S01 which had a lag phase of 1.5-2 h. Gradual rise in the optical density was observed after $4 \mathrm{~h}$ by the LAT9 whereas S01 exhibited rapid increase in optical density from $2 \mathrm{nd} h$ onwards. Two-way ANOVA was performed to analyse the significant difference between the growth of the strains. The asterisks indicate a significantly different optical density of two bacterial strains at various time points $(* \star \star p<0.001)$. Results are replicative of atleast 3 independent experiments. 
(a)

(b)

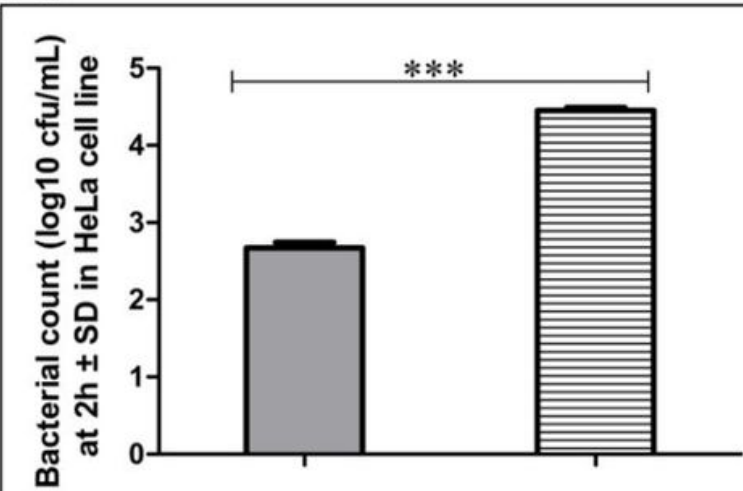

Salmonella strains

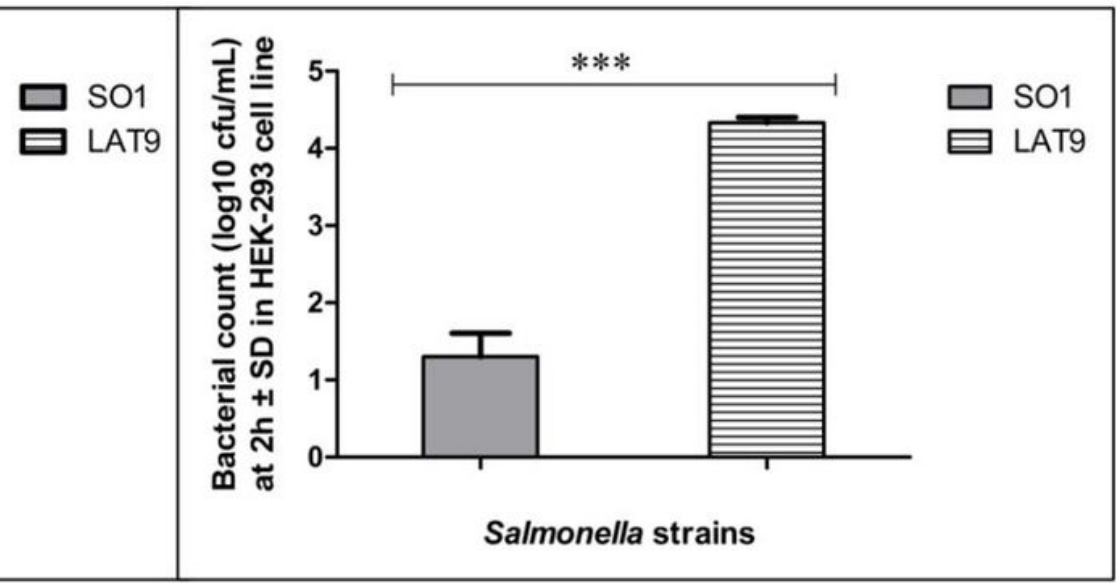

(c)

(d)

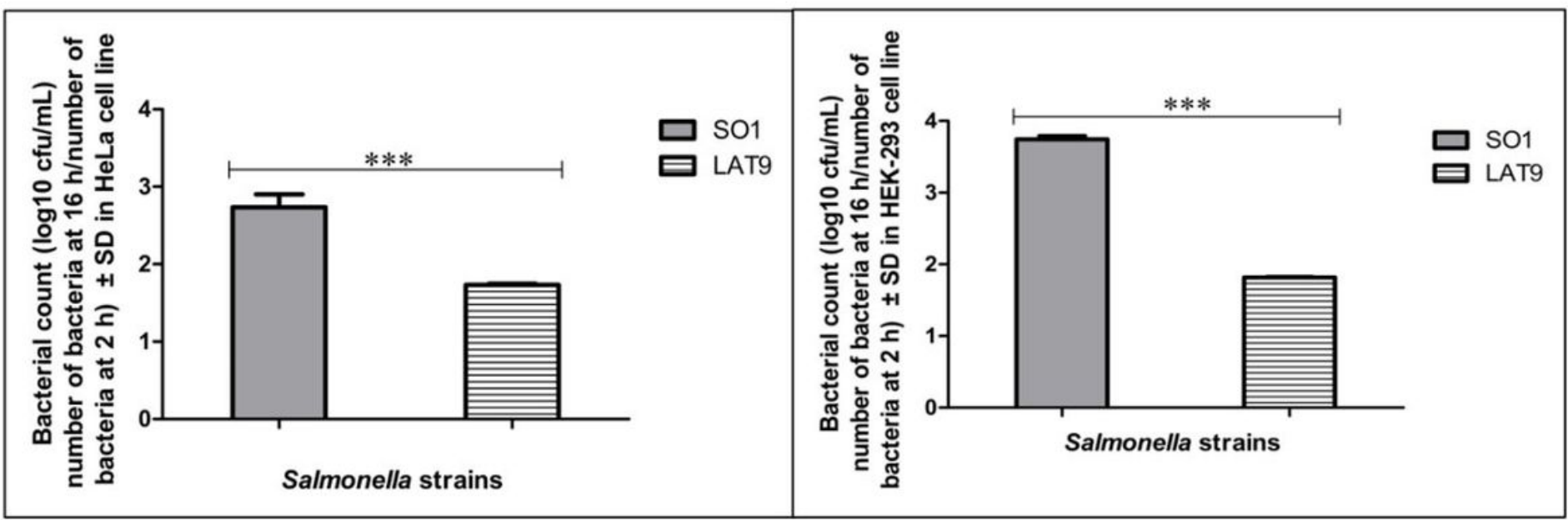

Figure 5

Epithelial cell invasion of SO1 and LAT9 at $2 \mathrm{hpi}(\mathrm{a}$ and b); Intracellular replication and survival of SO1 and LAT9 at 16 hpi (c and d) in HeLa and HEK-293 cell lines respectively. Unpaired t-test was used to find out the statistical significance between the strains. Data represent the mean \pm SD. The asterisks indicate a significantly different bacterial strains during epithelial cell invasion and intracellular replication in HeLa and HEK-293 cell lines $(* \star * p<0.001)$. Results are replicative of atleast 3 independent experiments 
(a)

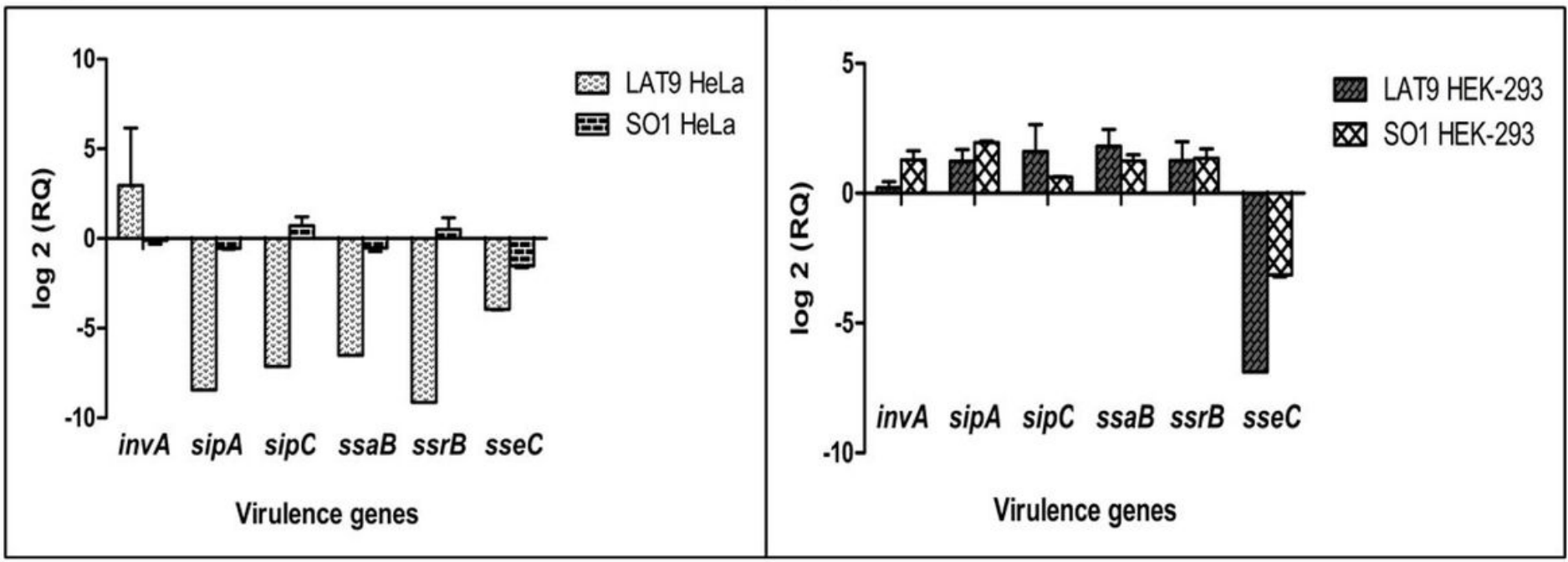

Figure 6

Graphical representation of the virulence gene expression on HeLa (a) and HEK-293 (b) cell lines at 6 hpi of LAT9 and S01. One-way ANOVA was used to check the statistical significance between the strains. Data represent the mean $\pm S D$. Results are replicative of atleast 3 independent experiments

\section{Supplementary Files}

This is a list of supplementary files associated with this preprint. Click to download.

- Supplementaryfigures.docx 